Copyright (C) 2021 by Cherkas Global University

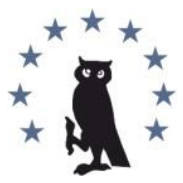

Published in the USA

Media Education (Mediaobrazovanie)

Has been issued since 2005

ISSN 1994-4160

E-ISSN 2729-8132

2021. 17(4): 593-600

DOI: $10.13187 / \mathrm{me} .2021 .4 .593$

https://me.cherkasgu.press

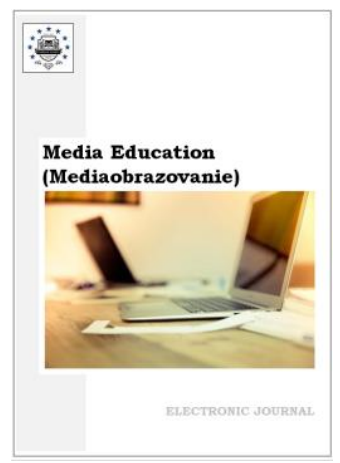

\title{
Humanitarian Orientations of Journalism Education. On the Materials of Expert Interviews
}

\author{
Marina Berezhnaia a, Sergey Korkonosenko ${ }^{a, *}$ \\ a Saint Petersburg State University, Russian Federation
}

\begin{abstract}
The article deals with the issues of the humanitarian nature and pedagogical attitudes of journalistic education, mainly in Russian universities. These topics have become more acute and sensitive in some relevant contexts. First, all over the world, and in Europe in particular, the contradictions between the traditional mission of universities as keepers of spiritual values and the concepts of entrepreneurial university have intensified. Second, the humanitarian traditions of higher education are under pressure from the rapid expansion of digital technologies. A new concept of humanitarian resistance has entered the teachers' professional vocabulary. Journalism education in Russia feels the influence of these contradictory contexts in full measure. In order to clarify the attitude of the teaching community to the changes taking place in this regard, the authors of the article conducted an expert interview with the heads of educational departments and professors from different regions of the country. This is the methodological basis of the article. Full videos of the conversations are presented on the special page of the research project "Theoretical and Pedagogical Schools of Journalism in Russia" (2019-2021), part of which were expert interviews. The study confirmed the hypothesis that Russian journalism teachers are committed to humanitarian values and educational traditions, although they are not opposed to technological and methodological innovations.
\end{abstract}

Keywords: journalistic education, Russian model, humanitarian orientations, expert interview, pedagogical school of journalism, teacher's personality.

\section{Introduction}

Under the influence of the economy globalization and increasing global competition, universities are strengthening their commercial activity and significantly changing the strategic guidelines of their activities. As the researchers of higher education note, one of the leading models is the entrepreneurial university, which "performs as a business structure, implements entrepreneurship programs, develops the entrepreneurial spirit towards students of different majors" (Prokhorov, 2016: 10). These metamorphoses cause different reactions in the pedagogical community, including far from approval. The dean of the Faculty of Social Sciences from University of Helsinki H. Nieminen writes: "Both scholars and policymakers largely agree that in the last 20 years European higher education policy has turned from policy based on democracy and culture towards policy driven by market-based ideals" (Nieminen, 2018: 73). Let's pay attention to the disturbing title of the article from which we took the quote: "In defence of European universities: Scholars and activists, unite!". In our opinion, the collision of two alternative approaches to education, namely technocratic managerism, on the one hand, and humanitarian education, on the

\footnotetext{
${ }^{*}$ Corresponding author

E-mail addresses: s.korkonosenko@spbu.ru (S.G. Korkonosenko)
} 
other hand, is clearly visible. In addition, the second approach, according to its adherents, is organically correlated with the mission of the university as a social institution and with the protection of national cultural priorities. It is no coincidence that "recently in Europe, issues of maintaining the national and cultural characteristics of European values and education systems have come to the fore... which seek to resist the increasing influence of the 'academic capitalism' of American higher education" (Naletova, 2018: 88). According to sociological researches, in Russia, the majority of teachers do not accept the reform of universities based on entrepreneurial values and remain committed to academic values (Mkrtychyan, Petrova, 2019: 147).

Disagreements and collisions of this kind can no longer be considered as peripheral phenomena or single episodes, they have moved to the level of systemic contradictions. The concept of humanitarian resistance has entered the pedagogical science, that is resistance to the reduction of the humanitarian component in education in favor of technologization and clientoriented relations (Murzina, 2020: 100). Education in the pandemic context has strengthened such sentiments among teachers, they began to perceive digitalization "not so much as technological modernization and the implementation of new carriers of educational information, but as a process threatening people and society ... as the loss of a meaningful component of life in favor of mechanical ... algorithms and standards" (Murzina, 2020: 107).

In turn, the humanitarian guidelines of journalistic education also become the subject of discussion in publications. Teachers pay attention to the fact that the previous state standard in this area assumed, first of all, humanitarian education and acceptance of the values of a socially significant creative profession. However, at present, journalism in the official list of specialties has moved from the group of "Humanities" to "Social Sciences" and took a place side by side with psychology, economics and management, sociology and social work, law, etc. (Myasnikova, 2020: 155). Changing the status inevitably entails corresponding shifts in the content and organization of the educational process. This means that there may be some responses from teachers both to the increasing technological modernization of education, and to decreasing the level of humanitarian culture of future journalists. Approving reactions will contribute to transformations, while a critical attitude towards them will become a factor of inhibition.

The purpose of this article is to find out the attitude of journalism teachers to humanitarian traditions and values in professional education and to their possible devaluation.

\section{Materials and methods}

The main method to achieve this goal was expert interviews with heads of educational organizations and well-known mentors from different cities and universities of Russia. This series of interviews covers a rather wide range of issues, of which the article presents only one thematic segment that corresponds to its topic.

For better understanding the context in which the conversation with experts was hold, we should clarify that it was an integral part of the comprehensive research project "Theoretical and Pedagogical Schools of Journalism in Russia" (2019-2021). The initiator and intellectual and methodological center of the work was the Department of the Theory of Journalism and Mass Communications of St. Petersburg State University, but representatives of a number of other departments and universities of Russia and abroad are involved in the collection and interpreting of materials. The project is aimed at solving the following tasks: a) to reconstruct the process of forming Russian theoretical and pedagogical schools of journalism; b) to identify their peculiar qualitative characteristics and achievements that can be considered as national cultural advantages; c) to use and develop methods of qualitative and quantitative analysis of schools; d) to present a series of professional and creative portraits of their outstanding representatives; e) to determine the main trends in the development of this branch of cognitive and educational activities. A detailed description of the project was presented in published materials (Korkonosenko, 2021), the results of the study appear regularly in academic periodicals (Berezhnaya, 2020; Blokhin, 2020; Khubetcova, 2019], all methodological documents and publications, as well as a portrait gallery of Russian journalism teachers, are posted on a specially created website (URL: https://www.journschools.com).

A total of 10 semi-structured interviews with a video recording were conducted in 2020-2021 for subsequent publication on the project's website (URL: https://www.journschools.com/ \%Do\%B2\%Do\%B8\%Do\%B4\%Do\%B5\%Do\%BE). The list of experts includes deans of journalism 
faculties, heads of departments and professors of specialized faculties, the head of a large professional educational project, as well as the creator of a journalism school for middle school students.

The high competence of the interlocutors makes it possible to overcome the methodological disadvantage, which British scholar Laurence Solkin revealed in 300 published contributions on journalism education: very few authors draw on any recognized educational resources or research. Despite extensive references to professionalisation in the literature, the works reviewed contain very few references to professional or experiential learning (Solkin, 2020: 12). Such arbitrary judgments cannot be considered trustworthy, while our experts rely on their experience gained over decades of work in journalism schools and freely operate with extensive literature on the issues under discussion.

The structure of the interview includes basic and variable semantic blocks, taking into account the field of activity and individual experience of concreate experts:

- conceptual (definition, interpretation, specification of concepts);

- informative (data on the development of certain schools, names, facts, examples, specifics);

- problematic (current state, challenges, prospects).

The humanitarian orientations of journalism education were touched upon in different blocks, to a certain extent it was a dominating motive of conversations, since the interlocutors chose this angle of view when discussing these or that aspects of the journalism schools' activities.

\section{Discussion}

Of course, the problems of humanitarization of journalism schools cannot be considered apart from the contexts in which the press itself and education exist. The broadest among them and at the same time opposing each other are the contexts of the global unification and preservation of national and cultural identity. It can be assumed that journalistic education is experiencing a powerful and multidirectional influence of both trends. In this light, it becomes clear the desire to fix its special features in certain regions against the global background. Large-scale projects covering the state of university journalism schools on a global level (Goodman, Steyn, 2017), in various parts of the world, for example, in Europe (Terzis, 2009) and Asia (Media Asia, 2008), in separate countries, for example, in Canada (Allen et al., 2015), etc., are aimed at solving this problem. On the other hand, attempts are being made to systematize various materials and identify typical models. So, according to Laurence Solkin, three approaches to journalistic education are reflected in the literature:

1) The standard model - A single unitary model of journalism as professional practice underpinned by a stable democratic free market system;

2) Derivatives of the standard model J.Ed+ - A pluralistic approach which recognizes that journalism is under threat and needs to develop especially in response to change in technology and the marketplace;

3) Radical models - A more explicit rejection of the standard model though the recognition that journalism education operates in many different ways depending upon context and can serve many different communities (Solkin, 2020: 9).

In all likelihood, the attitude to the humanitarian orientations of education will differ in accordance with the declared and implemented model. Moreover, the differences themselves can be identified precisely by the parameter of humanitarization. Turning to the Soviet decades (since journalism education was formed at a stable level during this period of history), it is easy to see that it was not the free market system which created ideological and semantic dominants in the domestic higher school. According to Russian professors, "contemporary journalism requires professionals, whose education is based on three basic pillars: knowledge of the society and its culture, knowledge of the nature of journalism, and knowledge of professional skills. Two pillars were present in the USSR already, and have been transformed into a new post-Socialist and digital reality of the Russian journalism education" (Vartanova, 2017: 22). Let's take into account that knowledge of the society and its culture is called in the first place. The conclusion follows that the Russian school of journalism cannot be related to the standard unitary model; rather, its place is among the so-called radical models that serve many certain communities.

Of course, it would be a wrong and unfair saying that all foreign teachers advocate "pure" professional skills, without components of humanitarian erudition (it would also be a mistake to assume that there are no supporters of "pure" labour technologies among Russian teachers). Foreign researchers also emphasize that it is impossible to limit educational programs to utilitarian 
instrumental training: "The role of the university is to prepare students not only to be employed but also to participate effectively and critically in the democratic community" (Reese, Cohen, 2000: 214); "journalism - and by extension journalism education - is an invaluable pillar in the workings of democracy" (Josephi, 2009: 50), etc. However, the ideas of our Russian colleagues extend far beyond the framework of democracy and social conjuncture, their reflections are being built on a broad worldview base and humanitarian priorities of the profession. It is characteristic, for example, that these motives are clearly heard when discussing pedagogical strategies: "The education of future professional journalists on the samples of a great worldview style, anthropocosmism, is seen as a promising educational strategy" (Poelueva et al., 2016: 13).

Thus, there are grounds for the hypothesis that expert interviews will express commitment to humanitarian orientations as an integral characteristic of the national school of journalism. Confirmation of this hypothesis (and after that active popularization of the Russian pedagogical ideology and experience) can be of considerable importance for partnership interaction with foreign universities. Until now, it has been hindered by the stereotypical representations and prejudices inherent in Western analysts. As some of them admit: "Entrenched ideological beliefs about totalitarian control over the academia prevented Western scholars from readily examining the broader historical and cultural context in which university journalism education developed in Russia” (Antonova et al., 2011: 140).

\section{Results}

The experts' sayings about the humanitarian components of education are grouped into three thematic blocks, relating to main aspects of the educational process: organizational and methodological, communicative, and professionally applied. In this order, they will be presented below.

1. At the organizational and methodological level, humanitarian priorities are manifested in the content and methods of teaching. Experts see journalist primarily in the roles of analyst, critic, and a thoughtful observer of the processes taking place in the world around him. In their opinion, this is a typical order for a university graduate. "University graduate makes an order for journalistic education. With the whole complex of problems, traditions, and cultural, economic, ethnolinguistic features of its development."

"We must understand that a journalist not only has basic skills, but he is a socialized person, he understands what is happening, can compare, analyze. Not every routine reporter's work needs such a qualification, but nevertheless, mental algorithms should be embedded in every person. And this is the humanitarian side of education, even the philosophical one."

"Philosophy, cultural studies, economics must necessarily be. As a result, widely educated people appear who can't write carelessly, for it is not interesting for them to write this way. An educated person has a deeper and more diverse understanding of life."

Experts associate fundamental socio-cultural training with the mission of higher education, and this conclusion clearly follows both from direct speech and from the context of statements. It is indicative that as a result, discourses about journalism and the university are actually closing in.

"If we produce people who can write at the level of basic skills, and then send them to the editorial offices, where they will improve their skills, - then higher educational institutions are not needed."

"We had a lot of meetings with the industry. We ask, what do you need? They say: students should to be educated. As to the formats, they say, we will teach them in one or two months, and our own formats."

"Without the humanitarian component of our education, including philological one, you can't teach journalism (it's not media communication). One of the main skills is a competent, expressive presentation of non-banal thoughts about what is happening around."

General attitudes determine approaches to the construction of curricula, the selection of disciplines, the invitation of teachers, the formation of teaching teams, etc. Experts on principle reasons reject disciplinary isolation and back up a broad interdisciplinary partnership.

"The school that is founded as the unity of education and upbringing and is built on certain views on journalistic education is not narrowed down to the set of teachers of proper journalism. Our school of St. Petersburg University is arranged in such a way that the best lecturers teach us literature - Russian and foreign, the best lecturers come from other faculties to teach courses in history, philosophy, etc. Bringing tutors of high university proficiency and intelligence to the journalists' audience is a conceptual solution." 
"I have been working at various departments of journalism for seventeen years, and, in my experience, it is important that the management of the department selects the appropriate teachers. First of all, for literary courses, including the history of Russian and foreign literature, as well as philosophical knowledge, ethics, and aesthetics. Unfortunately, this content is often withdrawn from education today."

"I am for fundamental humanitarian learning to be in the first place. For example, we have a good department of stylistics and literary editing, we pay a lot of attention to literature. Not only because we ourselves grew out of the philological faculty and many of us became candidates and doctors of philology. But also, because, after all, the word is the main thing in journalism."

Experts feel their belonging to journalism schools, which were built on a solid foundation of university culture. This means not only and not so much official affiliation, but mainly personal involvement in a stable tradition and way of activity.

"I consider myself a true product of the theoretical and educational school of journalism at Moscow University, which forces us all to look at objective reality and do research based on quantitative indicators, but it leaves us free to choose a position. Of course, the main thing here is the social responsibility of Russian journalism and its inclusion in the global context. I think that these are the distinctive features of the school to which I belong and which I am trying to develop, including the younger generation in it."

In this and similar judgments, one can found a harmonious combination of socio-cultural qualities common to all Russian journalism education with characteristics specific to a particular educational institution.

2. At the communicative level, interpersonal communication and the leading role of the individual in educational practice come to the fore. All the experts were willingly and in detail talking about the contribution to the education of its initiators, the leaders of pedagogical schools. The pedagogical community even associates the names of universities with the certain names of outstanding scientists and heads of faculties and departments.

"There are many personalities, several levels. But there is always a founder of a school who creates the mission, lays down certain values that are not subject to time, who cements this school with his works, textbooks or research articles and his personality."

"Every school should have its own traditions, its own gurus, followers and topics. So that people define in such words: 'Oh, is this a place where such and such persons work?"'.

"The first thing we remember is personalities. Leaders. In former years, when they talked about Moscow University, they remembered Dean Yassen Zassoursky, when they talked about Leningrad University, then Dean Alexander Berezhnoy."

Today's journalism schools are also marked with the names of their prominent representatives and authoritative researchers:

"Lazutina is engaged in deontology and ethics of journalism in Moscow. In St. Petersburg, Sidorov develops axiology, he has united people around him, arranges collections of articles and round tables; the school of text is represented by Misonzhnikov, Duskaeva, Konkov. In Rostov, Akopov and others developed a mass media typology, especially magazines. There are several directions on the Urals, for example, sociology, which was started by Sesyunin, supported by Lozovsky and Oleshko. Voronezh has always been known due to studies in publisism, there is a powerful school of Kroichik here, which was not in any other university."

There is no doubt that students are enriched by contacts with remarkable and bright figures who have earned recognition in academic spheres. In other words, belonging to a mature theoretical and pedagogical school is beneficial in itself. But since the interview concerns more education than academic research, the participants emphasize the importance of interpersonal communication for the professional formation of a graduate. On the one hand, the experience of masters, often unique, is transmitted through regular contacts.

"It is impossible to teach a journalist without direct human contact. This is the ABC."

"We are cooperating with Leonid Kolpakov, the first deputy editor-in-chief of the 'Literaturnaya Gazeta'. He has no journalism education, but he has been in journalism for twenty-five years, and worked in major media. He can tell much more about the profession than any theorist and methodologist who has thoroughly studied how to teach journalism." 
"We value every practical journalist as a teacher very much. We have interesting people: the editor-in-chief of the popular online media Thomas Tommingas, art critic and TV presenter, PHD in Philology Sergey Pakhachev... For us, such people are just worth their weight in gold."

On the other hand, the habit of communication and the corresponding abilities are part of the core of professional consciousness and activity.

"Journalistic education should help a graduate to master the main capital, the main skill that exists in the profession - it is called a person cognition."

Journalism teachers are acutely critical of the reduction of communication opportunities and the belittling of this educational resource.

"The founding fathers have passed us the principle: we should work with every student. But today, individual work stands not even on the third plan, but further on. We accept a large number of students, a big part of them is not motivated to study. This is happening simultaneously with the reduction of the staff. There is less and less time for individual work."

In recent months, the chronically relevant topic of lack of time has acquired additional nuances and sounded especially alarming in the pandemic context.

"The experience of working in isolation, at a distance showed how teachers and students long for direct communication. Apparently, distance learning is both useful and necessary as an additional tool, especially if we are talking about some kind of courses that cannot be studied in any other way. But distance cannot be a substitute for direct communication. Particularly when it comes to journalistic education."

"The leading universities included in the top global rankings offer their online classes. But despite this, students are still striving for a real place, for real teachers, not virtual ones. They strive for communication. The experience of teaching in self-isolation has shown this once again."

There is no reason to accuse the professionals who participated in the interview in conservatism and adherence to outdated academic schemes. As active actors in the production process and heads of structural departments of universities, they realistically assess and accept the need for changes, including personnel renewal.

"Today we focus on the fact that practical classes should be conducted by young journalists from the industry. I am beginning to understand and agree with this idea. Students are attentive to and interested in people who are close in age, but experienced in the profession."

"It is important for us that a teacher being a practitioner is able to work in new conditions. It is important to be ready to keep up with the times. There are many experienced journalists of the old formation who find no strength to step over their old habits and learn to work using new tools."

"We invite practitioners who have no teaching experience. At first, they complain that they have no skills. We say: don't be afraid, we are very interested, it's important what you do. And gradually, our specialists, who were afraid to speak a year and a half ago, are starting to teach not only here, but also at other venues."

As one can note, speaking for the renewal of personnel, experts are guided not by the cold logic of managerism, but by the desire to maximize the educational effect of interpersonal communication.

As expected, questions about the role of the individual and the mutual influence of people in the educational process constitute a large and very problematic section of the discourse on humanitarian orientations in the university training of journalists. It is noteworthy that none of the experts supported the idea of educational technologies without people or the priority of online learning over personal communication.

3. At the professional-applied (professional-ideological) level, the understanding of journalism as a humanitarian activity is placed in the center of attention, which in this case means working in contact with people and for people, carrying knowledge about people, etc. Vocational education is also oriented accordingly to preserve and transmit the basic values of the profession. Detailed declarations of this kind are found in the interviews texts.

"We must teach a person to understand that his work is for people, not to broadcast his selfunderstanding, but to be able to hear other people. There should be a lot of psychology in journalism now. So that the priority is not what I will say, but what I will hear in all these signs, events in the world and in society, and I will be able to convey it correctly, without misinforming the audience."

According to this and similar statements, experts advocate the ideology of active participation in public life and do not support either self-love and boundless self-expression, nor mimicry under 
neutrality and indifference towards subjects of public concern. In this regard, some of the interlocutors point to the national and cultural originality of Russian journalism.

"Our audience is waiting for the journalist's assessments and civic position. Such an interesting phenomenon as the combination of a journalist, a citizen and an activist in one person is typical only for Russia, it seems to me. European journalists describe civil activity, civil practices of participation, but they are not included in them themselves. Our journalists themselves begin to organize some kind of separate garbage collection or the green movement, or get involved in some feminist discourses."

Perhaps the distinction proposed between Russian and foreign journalists contains exaggeration. However, it is important to see the deontological basis of the expert's position: he makes a choice in favor of the high purpose of the profession and denies its prosaic interpretation. The denial concerns both the conjunctural requests of the industry ("The labor market is beginning to demand: we need the identical specialists with the identical set of technological skills, the identical understanding of their duties for those editorial offices that earn money"), and the organization of the educational process ("We are more and more aware of a certain limitation of the practice-oriented approach in those areas of activity that are related to the functioning of society and that are associated with the impact on public consciousness").

In practical terms, experts are concerned about destruction of the fundamental training, the simplification and unification of curricula, the fascination with technology, as well as the commercialization and pragmatization of education.

"The commercialization of education leads to that we accept everyone. I do not know how to teach in these conditions. We must close our eyes to the fact that there is a swamp. And the function of upbringing goes away completely."

"Unification is a bad future. The unification that exists in humanitarian university education is, you know, just the death of education completely."

"When I was drawing up an educational program, I was guided by the latest version of the educational standard. And it turned out that all general cultural competencies were replaced by universal competencies. The latter no longer presuppose the formation of solid knowledge in the sciences - philosophy, sociology, economics - as it was being done before."

These negative trends come into obvious contradiction with the humanitarian values and traditions of Russian journalistic education.

\section{Conclusion}

The performed research confirms the hypothesis about the commitment of representatives of various educational institutions to the humanitarian orientations, which are characteristic for the Russian educational tradition and the professional values of domestic journalism. To experts, in the context of continuing changes in the media sphere, these orientations seem to be an absolute constant. They determine the content basis of education and help us to preserve the semantic core of the profession, which is realized through the prism of social responsibility and humanitarian mission.

Experts point out that fundamental education and extensive humanitarian training extend the graduates' opportunities to find and acquire various options for professional self-realization. However, this basic value of Russian journalism schools may conflict with the current needs of the media market and the expansion of technological innovations.

The interview participants attach great importance to the personality of the teacher and emphasize the individual nature of pedagogical work in teaching journalism. In addition, according to their estimates, problem-thematic areas have priority in the activities of journalism schools, while instrumental skills are mandatory, but applied, as they are subject to market changes, unlike the social purpose and professional values of journalism. Experts advocate the preservation of the humanitarian basis of journalism education. In particular, they critically assess the unification of graduates' competencies, excessive passion for technology, shifting emphasis to practice-oriented training, etc. Together, these trends pose a threat not only to the continuity in the development of pedagogical schools in their traditional for Russia sense, but also to the effective functioning of journalism as a social institution.

\section{References}

Allen et al., 2015 - Allen, G., Craft, S., Waddell, Ch., Young, M.L. (eds.) (2015). Toward 2020: New directions in journalism education. Toronto: Ryerson Journalism Research Centre. 179 p. 
Antonova et al., 2011 - Antonova, S., Shafer, R., Freedman, E. (2011). Journalism education in Russia: Contemporary trends in a historical context. Journal of Global Mass Communication. 4(1-4): 133-151.

Berezhnaya, 2020 - Berezhnaya, M.A. (2020). Sotsial'naya zhurnalistika kak problemnotematicheskoe napravlenie $\mathrm{v}$ podgotovke zhurnalistov [Social journalism as a problem-thematic direction in the training of journalists]. In Blokhin, I.N., Khubetcova, Z.F., Marchenko, A.N. (eds.). Ocherki Peterburgskoi shkoly zhurnalistiki. St. Petersburg: 236-250. [in Russian]

Blokhin, 2020 - Blokhin, I.N. (2020). Peterburgskaya nauchno-pedagogicheskaya shkola zhurnalistiki: parametry i pokazateli analiza [Petersburg scientific and pedagogical school of journalism: parameters and indicators of analysis]. Vek informatsii. 8(3): 35-46. [in Russian]

Goodman, Steyn, 2017 - Goodman, R.S., Steyn, E. (eds.) (2017). Global journalism education in the 21st Century: Challenges and innovations. Austin: Knight Center for Journalism in the Americas, University of Texas at Austin. 493 p.

Josephi, 2009 - Josephi, B. (2009). Journalism education. In Wahl-Jorgensen, K., Hanitzsch, Th. (eds.). The handbook of journalism studies. N.Y.; London: Routledge: 42-56.

Khubetcova, 2019 - Khubetcova, Z.F. (2019). Nauchno-obrazovatel'nye shkoly zhurnalistiki stran blizhnego zarubezh'ya: reprezentatsiya i aprobatsiya metodiki analiza (na materialakh Belarusi, Kazakhstana i Ukrainy) [Theoretical and pedagogical journalism schools in post-soviet states: Representation and test methodology of analysis (on the materials of Belarus, Kazakhstan and Ukraine)]. Vestnik Volzhskogo universiteta imeni V.N. Tatishcheva. 4(1): 169-180. [in Russian]

Korkonosenko, 2021 - Korkonosenko, S.G. (2021). Nauchno-pedagogicheskie shkoly zhurnalistiki v Rossii [Theoretical and pedagogical schools of journalism in Russia]. Vek informatsii. 9(2): 11-18. [in Russian]

Media Asia, 2008 - Media Asia. Special Issue. Status and Relevance of Journalism Education in Asia (2008). 35(2).

Murzina, 2020 - Murzina, I.Y. (2020). Gumanitarnoe soprotivlenie v usloviyakh tsifrovizatsii obrazovaniya [Humanitarian resistance in the context of digitalisation of education]. Obrazovanie i nauka. 22(10): 90-115. DOI: 10.17853/1994-5639-2020-10-90-115 [in Russian]

Myasnikova, 2020 - Myasnikova, M.A. (ed.) (2020). Professional'naya kul'tura zhurnalista v usloviyakh mediatransformatsii [Professional culture of a journalist in the conditions of media transformations]. Yekaterinburg. 236 p. [in Russian]

Nieminen, 2018 - Nieminen, H. (2018). In defence of European universities: Scholars and activists, unite! In Peja, L., Carpentier, N., Colombo, F. et al. (eds.). Current perspectives on communication and media research. Bremen: Editions Lumiere: 73-82.

Poelueva et al., 2016 - Poelueva, L.A., Indrikov, A.A., Belyatskaya, A.A. (2016). "Vospitanie uma" protiv "summy tekhnologii": "bol'shoi stil" myshleniya i lingvokul'tura v professional'nom obrazovanii v sfere mass-media ["Mind upbringing" vs "technological progress": The "great style" of thinking and linguoculture in the professional mass media education]. In Kokhanaya, O.E. (ed.). Vysshee obrazovanie dlya XXI veka: XIII Mezhdunarodnaya nauchnaya konferentsiya. ... Professional'naya podgotovka $v$ sfere mass-media. Vol. 1. Moscow: 8-15. [in Russian]

Prokhorov, 2016 - Prokhorov, A.V. (2016). Predprinimatel'skii universitet: sushchnost' i priznaki [Entrepreneurial university: Main points and features]. Vestnik Tambovskogo universiteta. Seriya: Gumanitarnye nauki. 21. 2(154): 5-10. DOI: 10.20Reese310/1810-02012016-21-2(154)-5-10 [in Russian]

Reese, Cohen, 2000 - Reese, S.D., Cohen, J. (2000). Educating for journalism: The professionalism of scholarship. Journalism Studies. 1(2): 213-227.

Solkin, 2020 - Solkin, L. (2020). Journalism education in the 21st Century: A thematic analysis of the research literature. Journalism. 146488492097729: 1-17. DOI: $10.1177 / 1464884920977299$

Terzis, 2009 - Terzis, G. (ed.) (2009). European journalism education. Bristol (UK); Chicago (USA): Intellect. 544 p.

Vartanova, 2017 - Vartanova, E. (2017). Journalism education in Russia: Three main pillars. In Vartanova, E., Drok, N. (eds.). Zhurnalistskoe obrazovanie bez granits. Moscow: 21-22. [in Russian] 